\title{
PANDEMIC INFluenza A(H1N1) 2009 VACCINES IN THE EUROPEAN UNION
}

\author{
K Johansen (Kari.Johansen@ecdc.europa.eu) ${ }^{1}$, A Nicoll ${ }^{1}$, B C Ciancio ${ }^{1}$, P Kramarz $^{1}$ \\ 1. European Centre for Disease Prevention and Control, Stockholm, Sweden
}

This article was published on 15 October 2009.

Citation style for this article: Johansen K, Nicoll A, Ciancio BC, Kramarz P. Pandemic influenza A(H1N1) 2009 vaccines in the European Union. Euro Surveill. 2009;14(41):pii=19361. Available online: http://www.eurosurveillance.org/ViewArticle.aspx?ArticleId=19361

\begin{abstract}
Pandemic vaccines from four manufacturers are now available for use within the European Union (EU). Use of these vaccines will protect individuals and reduce the impact on health services to more manageable levels. The majority of the severely ill will be from known risk groups and the best strategy will be to start vaccinating in line with the recommendation from the European Union Health Security Committee prioritising adults and children with chronic conditions, pregnant women and healthcare workers. The composition of authorised vaccines is reviewed in this article. The vaccine strain in all authorised pandemic vaccines worldwide is based on the same initial isolate of influenza A/California/7/2009 (H1N1)v but the vaccines differ in conditions for virus propagation, antigen preparation, antigen content and whether they are adjuvanted or not. The vaccines are likely to be effective since no significant genetic or antigenic drift has occurred and there are already mechanisms for estimating clinical effectiveness. Influenza vaccines have good safety records and no safety concerns have so far been encountered with any of the vaccines developed. However, special mechanisms have been devised for the early detection and rigorous investigation of possible significant side effects in Europe through post-marketing surveillance and analysis. Delivery of the vaccines to the risk groups will pose difficulties where those with chronic illnesses are not readily identifiable to the healthcare services. There is considerable scope for European added value through Member States with excess vaccines making them available to other states.
\end{abstract}

\section{Introduction}

Vaccines from four manufacturers are now becoming available for protection against pandemic influenza A(H1N1) 2009 infection. Three vaccines have been authorised through the central European Medicines Agency (EMEA) mechanism for use in any European Union (EU) Member State (MS) and a fourth vaccine was recently authorised by the Hungarian National Regulatory Agency for use in Hungary (Table 1). The central mechanism was streamlined by rehearsal through use of mock-up protocols and experience of the development of human avian influenza vaccines including human clinical trial data. Within Europe, vaccination is known to have started in the Nordic countries and Hungary and will shortly begin in other EU countries. Pandemic vaccines have during the last few weeks been authorised for use in China, Australia and the United States (US), where vaccination campaigns have also begun.

The new vaccines are important countermeasures to mitigate the effects of pandemic waves in Europe however they are arriving too late and in too low quantities to stop population transmission. Instead, the vaccination strategy will have to be the usual one of influenza vaccination in Europe, namely that of protecting the vulnerable $[1,2]$.

Adherence to pandemic vaccine recommendations issued in the vaccine campaigns will be dependent on the current view of the pandemic in the general public, and more specifically among target groups recommended by the European Union Health Security Committee (HSC) / Early Warning and Response System (EWRS) for the initial rounds of vaccinations: healthcare workers, risk groups with underlying conditions and pregnant women [2]. Availability of sound data on safety and effectiveness will also be of importance.

\section{Vaccine composition}

The composition of the authorised European pandemic vaccines differ significantly in conditions for virus propagation, antigen preparation, antigen content and whether they are adjuvanted or not (Table 1).

The vaccine strain in pandemic vaccines worldwide is based on the initial isolate of influenza A/California/7/2009 (H1N1)v or a reassortment based on the same isolated strain and a more fastgrowing influenza $A(H 1 N 1)$ strain (PR8) which is called influenza $A /$ California/7/2009 (H1N1)v-like. No significant genetic or antigenic drift has occurred since the virus first was isolated in April 2009, which is why these vaccines are expected to be effective against the pandemic waves expected in Europe this winter season. However, the ability of a pandemic influenza vaccine to evoke an immune response against drifted influenza viruses that are different from those included in the formulation would obviously be of major clinical value $[3,4]$ - if such a drift should occur.

Due to limitations in vaccine supply worldwide in the case of a pandemic and the propensity of influenza viruses to antigenic drift, the World Health Organization encouraged development of vaccines with adjuvants when avian flu vaccines were developed. The term is derived from the Latin 'adjuvans' meaning 'to help'. Adjuvants have been used for many years in many vaccines with good effect. In influenza vaccines they can reduce the dose of antigen needed to produce the same immunological (protective) response and improve their ability to provide longer-lasting protection broad enough to cover many antigenic drifted variants. They work naturally by prolonging the exposure time of antigen to the immune system, enhancing the delivery of antigen to antigen-presenting cells, and 
providing immunostimulatory signals that potentiate the immune response [5]. In the three current adjuvanted pandemic vaccines the oil-in-water adjuvants (squalene-based) and the aluminium phosphate adjuvant have allowed reduction of the haemagglutinin content per dose by a factor of between two and eight $(7.5 \mu \mathrm{g}$ to $1.875 \mu \mathrm{g} /$ dose) compared to seasonal influenza vaccines ( $15 \mu \mathrm{g} /$ dose) (see Table 1). Squalene is both a natural intermediate product of endogenous human cholesterol metabolism and a component of human cell membranes. It is constantly detected in human blood. It is also found in fish liver oil and vegetable oil $(\sim 0.7 \%$ in olive oil). When ingested, about $60-80 \%$ of squalenes are absorbed from the intestinal tract. The product for vaccine production is isolated from shark liver. There is already a large body of experience from their use in vaccines for humans. No safety concerns of clinical significance have arisen in more than 70 clinical trials with squalene-containing adjuvants. A seasonal influenza vaccine containing the MF59 adjuvant, Fluad, has been used since 1997 with over 40 million doses distributed. The MF59 safety database includes to this date information on more than 20,000 individuals [6]. The ASO3 adjuvant contains two oils, squalene and DL-atocopherol (vitamin E), both with immunostimulating capacity. $\mathrm{DL}$-a-tocopherol is a nutrient and the daily requirement for humans is 20-30 mg. The safety database for ASO3 includes more than 10,000 individuals [personal communication GSK Biologicals].

Both squalene-based adjuvants, MF 59 and AS03, have been shown to induce more local or systemic reactions within three days of vaccination than non-adjuvanted vaccines but there are no major reactions reported $[6,7]$.

The aluminium phosphate adjuvant has been used extensively in vaccines for the past 5-6 decades, and particularly in Hungary in the seasonal influenza vaccine, and has enabled the manufacturer to reduce the dose almost three-fold (see Table 1) [8].
One of the European pandemic vaccines is non-adjuvanted. This is an inactivated wild-type whole-virion vaccine. To reduce early experiences with seasonal influenza vaccines with increased reactogenicity seen with vaccines based on the whole-virion concept compared to split and subunit vaccines, current manufacturer have made a dose-reduction of the haemagglutinin from $15 \mu \mathrm{g}$ to $7.5 \mu \mathrm{g}$ per dose (see Table 1) and shown that they still provide a robust immune response [9-10].

Three pandemic vaccines contain thiomersal thiosalicylate (ethylmercury, containing $49.6 \%$ mercury per weight), a long-used mercury-containing preservative needed to maintain sterility in many vaccines during production and in their final injectable form. The pandemic vaccines contain thiomersal in varying concentration from 5 to $50 \mu \mathrm{g}$ per dose (see Table 2). Mercury is commonly found as an environmental contaminant in foods, notably in fish and seafood, principally in the form of methylmercury. While exposure to methylmercury varies by country, intake estimates for European consumers are close to internationally established safe intake limits. The Joint FAO/WHO Expert Committee on Food Additives (JECFA) has established a Provisional Tolerable Weekly Intake (PTWI) of $1.6 \mu \mathrm{g} / \mathrm{kg}$ body weight [11]. Acknowledging that there are different chemical forms of mercury: elemental, inorganic and organic, the conclusion is that in view of the recommendations for food products the total dose of thiomersal provided in one or two doses of pandemic vaccine is regarded to be of little significance and harmless to those vaccinated, which is also the experience from many years of its use in other vaccines [12-16].

\section{Induced immunogenicity}

The current European recommendation of two doses for the three centrally authorised vaccines (see Table 1) separated by at least three weeks are based on clinical trials with the avian flu vaccines when two doses were generally needed to achieve a good immunological response [17-19]. Initial reports on immunogenicity

T A B L E

Overview of vaccines against pandemic influenza $A(H 1 N 1)$ available in the European Union in October 2009

\begin{tabular}{|c|c|c|c|c|c|}
\hline Name, producer & Product description & Culture medium & $\begin{array}{c}\text { Haemagglutinin- } \\
\text { content }\end{array}$ & Adjuvant emulsion & $\begin{array}{l}\text { Number } \\
\text { of doses }\end{array}$ \\
\hline $\begin{array}{l}\text { Celvapan, } \\
\text { Baxter }\end{array}$ & $\begin{array}{l}\text { Inactivated, whole } \\
\text { wild-type virus } \\
\text { A/California/7/2009 (H1N1)v }\end{array}$ & Cell-culture & $7.5 \mu g$ & None & $\begin{array}{c}\text { All }>6 \text { months } \\
2 \times 0.5 \mathrm{~mL}\end{array}$ \\
\hline \multirow{2}{*}{$\begin{array}{l}\text { Pandemrix, } \\
\text { GSK }\end{array}$} & \multirow{2}{*}{$\begin{array}{c}\text { Inactivated, } \\
\text { split-influenza, reassortant, A/California/7/2009 } \\
(\text { H1N1)v-like strain }\end{array}$} & \multirow{2}{*}{ Egg-culture } & $\begin{array}{c}3.75 \mu g \text { (per adult } \\
\text { dose) }\end{array}$ & \multirow{2}{*}{ AS03 } & $\begin{array}{l}>10 \text { years } \\
2 \times 0.5 \mathrm{~mL}\end{array}$ \\
\hline & & & $\begin{array}{c}1.875 \mu g \text { (per } \\
\text { pediatric dose) }\end{array}$ & & $\begin{array}{c}6 \text { months }-9 \text { years } \\
2 \times 0.25 \mathrm{~mL}\end{array}$ \\
\hline $\begin{array}{l}\text { Focetria, } \\
\text { Novartis }\end{array}$ & $\begin{array}{l}\text { Inactivated, surface-influenza antigens } \\
\text { (haemagglutinin and neuraminidase), } \\
\text { reassortant, A/California/7/2009 (H1N1)v-like } \\
\text { strain }\end{array}$ & Egg-culture & $7.5 \mu \mathrm{g}$ & MF59 & $\begin{array}{c}\text { All }>6 \text { months } \\
2 \times 0.5 \mathrm{~mL}\end{array}$ \\
\hline $\begin{array}{l}\text { Fluval P, } \\
\text { Omninvest }\end{array}$ & $\begin{array}{c}\text { Inactivated, whole } \\
\text { reassortant virus } \\
\text { A/California/7/2009 (H1N1)v-like strain }\end{array}$ & Egg-culture & $\begin{array}{c}6 \mu g \text { (per adult dose) } \\
3 \mu \mathrm{g} \text { (per pediatric } \\
\text { dose) }\end{array}$ & $\begin{array}{l}\text { aluminium } \\
\text { phosphate }\end{array}$ & $\begin{array}{c}\text { Adults and adolescents }>12 \\
\text { years } \\
1 \times 0.5 \mathrm{~mL} \\
\text { Children } 3-12 \text { years } \\
1 \times 0.25 \mathrm{~mL} \\
\text { Children } 6 \text { months - } 3 \text { years* } \\
1 \times 0.25 \mathrm{~mL} \text { (*decision pending) }\end{array}$ \\
\hline
\end{tabular}


using non-adjuvanted and adjuvanted pandemic vaccines from several companies have concluded that a single dose of pandemic vaccine provides an unexpectedly good immune response [20,21]. It is good news that the vaccine strain is so immunogenic and most probably provides rapid protective immunity in the majority of vaccinated individuals. Immunogenicity data from clinical trials using the current pandemic vaccines authorised in Europe will soon become available and if possible the Committee for Medicinal Product for Human Use (CHMP) at the EMEA will then consider whether to adjust the recommendations for all or specific age groups. However, it will be important to determine how long-lasting this immune response will be and EMEA has therefore so far taken a safe course of relying on the evidence from the clinical trials with avian flu vaccines that two doses are needed for a robust long-term immune response.

The long-term immune response will be followed closely in vaccinated individuals and if subsequently one dose is deemed enough to provide a sustained protective immunity at least in healthy adults, more vaccine doses will become available for populations currently not targeted for the initial vaccine doses. However, it is quite possible based on previous experience that young children, individuals with congenital or acquired immunodeficiences and susceptible elderly will need two doses for obtaining a good longterm immune response that will protect them through the whole 2009-10 season.

One European manufacturer of pandemic vaccine (Omninvest, Hungary) recommends one dose to all age groups based on trials with the avian and H1N1 influenza vaccine (Table 1) [8,22].

\section{Vaccine effectiveness}

Immunogenicity does not directly reflect high effectiveness but with the use of specific pandemic vaccines against viruses that

\section{T A B L E 2}

Overview of thiomersal and immunostimulating compounds* included in vaccines against pandemic influenza $A(\mathrm{H} 1 \mathrm{~N} 1)$ available in the European Union in October 2009

\begin{tabular}{|c|c|c|}
\hline & Thiomersal & Adjuvant emulsion \\
\hline $\begin{array}{l}\text { Celvapan, } \\
\text { Baxter }\end{array}$ & No & None \\
\hline $\begin{array}{l}\text { Pandemrix, } \\
\text { GSK }\end{array}$ & $\begin{array}{c}5 \mu g \text { (per adult dose) } \\
2.5 \mu g \text { (per pediatric } \\
\text { dose) }\end{array}$ & $\begin{array}{c}\text { AS03 } \\
\text { squalene* } 10.69 \mathrm{mg} \\
\text { a-tocopherol* } 11.86 \mathrm{mg} \\
\text { polysorbate } 804.86 \mathrm{mg} \\
\text { per adult dose; } \\
\text { half the above amounts per } \\
\text { pediatric dose }\end{array}$ \\
\hline $\begin{array}{l}\text { Focetria, } \\
\text { Novartis }\end{array}$ & $50 \mu g$ & $\begin{array}{c}\text { MF59 } \\
\text { squalene* } 9.75 \mathrm{mg} \\
\text { polysorbate } 801.175 \mathrm{mg} \\
\text { sorbitan trioleate } 1.175 \mathrm{mg}\end{array}$ \\
\hline $\begin{array}{l}\text { Fluval P, } \\
\text { Omninvest }\end{array}$ & $\begin{array}{c}50 \mu g \text { (per adult dose) } \\
25 \mu \mathrm{g} \text { (per pediatric } \\
\text { dose) }\end{array}$ & $\begin{array}{c}\text { aluminum phosphate } \\
0.33 \mathrm{mg} \mathrm{Al}^{3+} \\
\text { (per adult dose) } \\
0.165 \mathrm{mg} \mathrm{Al}^{3+} \\
\text { (per pediatric dose) }\end{array}$ \\
\hline
\end{tabular}

are not drifted, vaccine effectiveness is expected to be good. In a pandemic context vaccine effectiveness data should be provided by age group, by number of doses received, and by vaccine brand. This requires very large sample sizes in order to produce reliable effectiveness data in time to contribute to the success of vaccination campaigns. Vaccine effectiveness will be studied on a European level through a project funded by the European Centre for Disease Prevention and Control (ECDC) involving study centres in ten countries (I-MOVE project, coordinated by a research group EpiConcept) [23]. These studies will be based on networks of physicians reporting influenza-like illness (ILI) cases undergoing laboratory testing for influenza. Manufacturers may also undertake separate studies of pandemic vaccine effectiveness as recommended by EMEA. They may use study protocols developed as part of the I-MOVE project and posted on ECDC web portal to improve comparability between studies [24,25].

\section{Vaccine safety}

The safety of the vaccines is of prime concern to the authorities and the public. The safety profiles already observed with seasonal and the human avian flu vaccines containing similar compounds including adjuvants will be applicable to the corresponding vaccines containing the influenza $A(H 1 N 1) 2009$ pandemic strain and they have been well tolerated. The pandemic $\mathrm{H} 1 \mathrm{~N} 1$ vaccines from all European manufacturers used in the ongoing clinical trials in healthy children, adults and elderly have so far been well tolerated with only minor side effects. The authorised pandemic $\mathrm{H} 1 \mathrm{~N} 1$ vaccines undergo the same rigorous manufacturing oversight, product quality testing and lot release procedures that apply to seasonal influenza vaccines. EMEA has in its reviewing process evaluated all available published and unpublished safety data [26] for the three centrally authorised pandemic vaccines and so far has found no safety signals that might indicate an increased risk following the use of these vaccines.

At this stage longer-term safety data cannot be available and associations with very rare conditions can only be ruled out by careful post-marketing surveillance. This is always the case with new vaccines and medicines in general at the moment of their introduction. Those monitoring vaccine safety, will keep a special watch for increased incidence of Guillain-Barre syndrome (GBS). GBS is a rare condition and may be associated with several infections; campylobacter, influenza and Epstein-Barr virus [27]. GBS was observed with one crude $A(H 1 N 1)$ vaccine derived from an influenza of swine origin and used in the US in the 1976-7 influenza season. The observed attributable risk for all age groups in the six weeks after vaccination was around nine cases per million vaccines [28]. As the exact causal mechanism of this phenomenon has never been elucidated health officials worldwide will be on alert for reports of GBS this year. However, the overwhelming evidence, including the best study to date in Europe, points to no association of GBS with seasonal influenza vaccines, but instead a documented significant association of GBS with influenza infection itself [29].

Post-marketing surveillance is therefore crucial and will take a number of forms. The routine spontaneous pharmacovigilance system within EU Member States will continue and reports will be sent as usual to the EMEA Eudravigilance database. In addition manufacturers are required to send simplified periodic safety update reports (PSURs) to EMEA. These are usually required on a six-month basis but that has been reduced to monthly reporting. In addition, ECDC in collaboration with a consortium of researchers 
(VAESCO) are developing complementary vaccine safety monitoring and hypothesis testing through linkage of large computerised clinical databases and immunisation registries (http://vaesco.net/ internet/en/index.html) [30].
As with many vaccines, several of the pandemic vaccines are being produced in formulations that contain thiomersal. Multiple analyses showed no increased risk of adverse events associated

\section{T A B L E 3}

Recommendations and guidance of various bodies concerning priority groups / target groups for specific pandemic vaccines against pandemic influenza $\mathrm{A}(\mathrm{H} 1 \mathrm{~N} 1) 2009$

\begin{tabular}{|c|c|c|c|c|}
\hline $\begin{array}{l}\text { Key contents from the } \\
\text { three organisations }\end{array}$ & $\begin{array}{l}\text { World Health } \\
\text { Organization Strategic } \\
\text { Advisory Group of } \\
\text { Experts } \\
\text { (7 July 2009) }\end{array}$ & $\begin{array}{l}\text { United States Centers } \\
\text { for Disease Control and } \\
\text { Prevention Advisory } \\
\text { Committee on Immunization } \\
\text { Practices } \\
\text { (28 August 2009) Limited } \\
\text { supply }\end{array}$ & $\begin{array}{l}\text { United States Centers for Disease } \\
\text { Control and Prevention Advisory } \\
\text { Committee on Immunization } \\
\text { Practices } \\
\text { (28 August 2009) Plentiful supply } \\
\text { option }\end{array}$ & $\begin{array}{l}\text { European Union Health Security } \\
\text { Committee } \\
\text { (25 August 2009) }\end{array}$ \\
\hline $\begin{array}{l}\text { General considerations and } \\
\text { criteria for selecting the } \\
\text { priority and target groups }\end{array}$ & $\begin{array}{l}\text { 'SAGE suggests the } \\
\text { following groups for } \\
\text { consideration, noting } \\
\text { that countries need } \\
\text { to determine their } \\
\text { order of priority based } \\
\text { on country-specific } \\
\text { conditions:' }\end{array}$ & $\begin{array}{l}\text { 'ACIP recommends that } \\
\text { vaccination efforts should } \\
\text { focus initially on persons in } \\
\text { five target groups (below). } \\
\text { In the event that vaccine } \\
\text { availability is unable to } \\
\text { meet initial demand, priority } \\
\text { should be given to a subset of } \\
\text { the five target groups (below).' } \\
\text { No priority order between } \\
\text { the categories below }\end{array}$ & $\begin{array}{c}\text { 'ACIP recommends that vaccination } \\
\text { efforts should focus initially } \\
\text { on persons in five target groups } \\
\text { (below).' } \\
\text { No priority order between the } \\
\text { categories below }\end{array}$ & $\begin{array}{l}\text { 'It should be stressed that } \\
\text { it is within the mandate and } \\
\text { responsibility of Member States } \\
\text { to develop a vaccination strategy } \\
\text { for influenza A(H1N1) 2009.' } \\
\text { No priority order between the } \\
\text { categories below }\end{array}$ \\
\hline \multirow[t]{7}{*}{ Priority and target groups } & $\begin{array}{l}\text { Healthcare workers } \\
\text { - all countries should } \\
\quad \text { immunise their } \\
\text { healthcare workers as a } \\
\text { first priority to protect } \\
\text { the essential health } \\
\text { infrastructure }\end{array}$ & $\begin{array}{l}\text { Healthcare workers and } \\
\text { emergency medical services } \\
\text { personnel - who have direct } \\
\text { contact with patients or } \\
\text { infectious material }\end{array}$ & $\begin{array}{l}\text { Healthcare and emergency } \\
\text { medical services personnel }\end{array}$ & Healthcare workers \\
\hline & $\begin{array}{l}\text { Pregnant women - since } \\
\text { this group appears to } \\
\text { be at increased risk for } \\
\text { severe disease. }\end{array}$ & Pregnant women & Pregnant women & Pregnant women \\
\hline & $\begin{array}{l}\text { Individuals aged }>6 \\
\text { months with one of } \\
\text { several chronic medical } \\
\text { conditions - in order } \\
\text { to reduce morbidity and } \\
\text { mortality }\end{array}$ & $\begin{array}{l}\text { Children and adolescents } \\
\text { aged 5-18 years who } \\
\text { have medical conditions } \\
\text { that put them at higher } \\
\text { risk for influenza-related } \\
\text { complications }\end{array}$ & $\begin{array}{l}\text { Persons aged 25-64 years who } \\
\text { have medical conditions that } \\
\text { put them at higher risk for } \\
\text { influenza-related complications. }\end{array}$ & $\begin{array}{l}\text { All persons from } 6 \text { months of } \\
\text { age up with underlying chronic } \\
\text { conditions - increasing the } \\
\text { risk for severe disease, starting } \\
\text { with the ones who have a severe } \\
\text { underlying condition (e.g. severe } \\
\text { asthma, unstable coronary heart } \\
\text { disease, uncompensated heart } \\
\text { failure, etc.) }\end{array}$ \\
\hline & $\begin{array}{l}\text { Healthy young adults } \\
\text { (aged >15 years and } \\
\text { <49 years) to reduce } \\
\text { morbidity and mortality }\end{array}$ & $\begin{array}{l}\text { Persons who live with or } \\
\text { provide care for infants aged } \\
<6 \text { months }\end{array}$ & $\begin{array}{c}\text { Persons who live with or provide } \\
\text { care for infants aged }<6 \text { months } \\
\text { (e.g. parents, siblings and daycare } \\
\text { providers) }\end{array}$ & \\
\hline & Healthy children & $\begin{array}{l}\text { Children aged } 6 \text { months to } \\
4 \text { years }\end{array}$ & $\begin{array}{c}\begin{array}{c}\text { Persons aged } 6 \text { months to } 24 \\
\text { years }\end{array} \\
\end{array}$ & \\
\hline & $\begin{array}{l}\text { Healthy adults aged }>49 \\
\text { years and }<65 \text { years to } \\
\text { reduce morbidity and } \\
\text { mortality }\end{array}$ & & & \\
\hline & $\begin{array}{l}\text { Healthy adults aged } \\
\text { >65 years to reduce } \\
\text { morbidity and mortality }\end{array}$ & & & \\
\hline
\end{tabular}


with thiomersal-containing vaccines. Based on a recent review, Global Advisory Committee on Vaccine safety (GACVS) concluded that "there is no evidence supporting any change in WHO's recommendations for thiomersal-containing vaccines" [31].

\section{Risk benefit analyses and risk communication for making informed choices}

Risk benefit analysis is more difficult than usual given an infection that has mild effect on most people but causes severe disease in some individuals, nevertheless it is clear that people in the target groups should be immunised including healthcare workers $[32,33]$. A European strategy for benefit-risk monitoring of the pandemic influenza $A(\mathrm{H} 1 \mathrm{~N} 1)$ vaccine has been agreed upon by EMEA and ECDC. It is important that those being offered the vaccines are given clear guidance and information on the likelihood of them being affected by the pandemic influenza A(H1N1) 2009 virus and of experiencing severe outcomes to enable them to make informed choices. The most recent risk assessment from ECDC reports the experience from countries in the southern hemisphere temperate zone. These are countries that have experienced the first winter of transmission [33]. While it cannot be assumed that the experience in Europe will be identical they give the best broad idea of what can be expected [34]. In countries such as Australia, Chile and New Zealand clinical attack rates were not high. However, there were pressures experienced by primary care and hospital services, especially intensive care units $[35,36]$. The demand on secondary and higher levels of care have mostly, though not entirely, come from sick people from the risk groups (Table 3). Hence the emphasis on these groups recommended by the European Union Health Security Committee (HSC) / Early Warning and Response System (EWRS) [2,37]. Individuals with chronic underlying diseases are at greater risk of developing severe disease. Among the hospitalised and fatal cases, $60-70 \%$ suffer from some underlying condition [38]. Estimates for case fatality rates are under $0.1 \%$ but it is still expected that most pandemic influenza-associated deaths will be in younger adults (those under the age of 60 years) [36]. This estimated case fatality rate is lower than seen in any of the 20th century pandemics. It should be mentioned here that 12-22 deaths per week have been observed in EU and EEA Member States since 1 September 2009.

Among healthy individuals, pregnant women and young children are at greatest risk of severe disease [39]. In the US the estimated rate of admission to hospital has been four to five times higher in pregnant women than in the non-pregnant women general population (0.32 per 100,000 pregnant women, $95 \% \mathrm{Cl} 0.13-$ 0.52 vs 0.076 per 100,000 population at risk, $95 \% \mathrm{Cl} 0.07-0.09$ ). Whether the risk of severe disease increases with gestational age, as it does for seasonal influenza, is not known yet [40]. Providing vaccines to pregnant women will also protect their infants through maternal antibodies as these children cannot be immunised until six months of age. The description of the first fatal case series in children has been published in the US and it is expected that this information will inform parents' decisions [41]. Similarly to cases in adults, chronic underlying conditions were a risk factor and only a third of the children who died had previously been healthy.

These kinds of data are not yet available from Europe and apart from the above US study concerning pregnant women, more analyses are necessary to answer the questions EU citizens offered vaccination will reasonably ask: If I am affected what is my risk of going into hospital or dying from the infection? What is the risk for my asthmatic son? My handicapped sister? My elderly father? We also need to be sure that the risk groups are the same for Europe as they are for North America and the southern hemisphere [42].

The overall picture is complicated by the fact that although there are some healthy people who experience severe disease in this pandemic (usually they constitute up to $30 \%$ of a series of severe cases) the indications are that most of those infected will experience a mild self-resolving disease. Hence the challenge for those promoting vaccination to healthy people is considerable. They have to convey that if healthy adults and children are infected they will most likely not get very ill, however, at the same time there is a small risk of severe disease or even death. For healthcare workers it is important to ensure that vaccines are readily available and to remind them of their responsibility not to infect their much more vulnerable patients [43].

\section{Vaccination scares}

With the implementation of the vaccination campaigns there will be vaccine scares because of coincidence alone, i.e. temporal but not necessarily causal association [44]. For example with the average background incidence of GBS of 1-2 cases per 100,000 population per year it can be expected that in a country of 20 million inhabitants 200-400 cases of GBS per year or four to eight cases per week are registered [45]. If some of these cases occur in temporal proximity to vaccination, concerns may be raised about the association with the vaccine. Special challenges for safety surveillance are related to the fact that some of the groups being immunised initially, such as pregnant women and people with chronic illnesses, are anyway more likely to experience complications including spontaneous abortion or reactivation of the chronic disease. Proper and timely investigation of suspected cases and rapid assessment will be crucial. From recent experience, for example with the HPV vaccines, it can be expected that once proper investigations are undertaken the scares will most often turn out to be the result of coincidence not causation. However that will not be assumed and plausible (and probably some nonplausible), observed associations will be investigated and tested. One attractive prospect of European added value is that observations and a hypothesised relationships from one country can be tested in several other countries enlarging the sample size to test and data may be shared.

\section{Vaccine availability and delivery}

The newly authorised pandemic vaccines are now available to European populations. The challenging problem is that much of the manufacturing capacity is already spoken for through advance purchasing contracts held by some but not all European countries. In addition, vaccines will be produced gradually, so initially there will be a limited supply of vaccine doses in Europe and elsewhere. Prioritisation activities have therefore been viewed necessary.

Several governmental and other official organisations worldwide have provided guidance or recommendations on who should be offered vaccine first [46] (Table 3). The priority groups identified in the Table should serve as indication only and countries may wish to adapt, and some have already done so, the prioritisation in line with their epidemiology, health service provision and resources. All organisations have listed healthcare workers, pregnant women and persons with underlying medical conditions as the first three priority groups. These groups were also agreed on by EU Member States through the Health Security Committee (HSC) and Early Warning and Response System (EWRS) [2]. Vaccinating people with chronic 
conditions will be difficult in countries where primary care services do not maintain ready lists of such individuals.

The World Health Organization has asked wealthy countries to help poorer ones to purchase limited amounts of these vaccines - cost should not be a barrier to access. A number of the best provisioned European countries and vaccine manufacturers have stated that they would make available vaccine doses to WHO for further distribution. What will be equally challenging is the distribution of vaccines within Europe. Risk will be distributed more evenly than supply. Seasonal influenza vaccines are used very unevenly in Europe. For example, vaccine coverage among people aged 65 years and older varies 40-fold on a per capita basis [47]. If only single doses are needed after review of immune responses to the various vaccines then there will be reasonable expectations that countries ordering late may be able to purchase vaccines from countries that ordered early in large volumes. This possibility was envisaged at the extraordinary EU Health Council under the Swedish Presidency on 12 October [48]. There are contractual and liability barriers that will need to be solved but it should be hoped that the sharing of influenza vaccines will show a good example of European added value.

\section{References}

1. Nicoll A, Ciancio BC, Tsolova S, Blank PR, Yilmaz C. The scientific basis for offering seasonal influenza immunisation to risk groups in Europe. Euro Surveill. 2008;13(43):pii=19018. Available from: http://www.eurosurveillance. org/ViewArticle.aspx?ArticleId $=19018$

2. European Union Health Security Committee (HSC) / Early Warning and Response System (EWRS). HSC/EWRS statement on influenza A(H1N1) 2009: target and priority groups for vaccination. 25 August 2009 [cited 15 October 2009]. Available from: http://ec.europa.eu/health/ph_threats/com/Influenza/docs/ HSC_EWRS_statement_en.pdf

3. Leroux-Roels I, Borkowski A, Vanwolleghem T, Dramé M, Clement F, Hons E, et al. Antigen sparing and cross-reactive immunity with an adjuvanted rH5N1 prototype pandemic influenza vaccine: a randomised controlled trial. Lancet. 2007;370(9587):580-9.

4. Chu DW, Hwang SJ, Lim FS, Oh HM, Thongcharoen P, Yang PC, et al. Immunogenicity and tolerability of an ASO3(A)-adjuvanted prepandemic influenza vaccine: phase III study in a large population of Asian adults. Vaccine. 12 August 2009 [Epub ahead of print]. doi:10.1016/j.vaccine.2009.07.102.

5. Atmar RL, Keitel WA. Adjuvants for pandemic influenza vaccines. Curr Top Microbiol Immunol. 2009;333:323-44.

6. Pellegrini M, Nicolay U, Lindert K, Groth N, Della Cioppa G. MF59-adjuvanted versus non-adjuvanted influenza vaccines: Integrated analysis from a large safety database. Vaccine. 12 September 2009 [Epub ahead of print]. doi:10.1016/j.vaccine.2009.08.101.

7. Rümke HC, Bayas JM, de Juanes JR, Caso C, Richardus JH, Campins M, et al. Safety and reactogenicity profile of an adjuvanted H5N1 pandemic candidate vaccine in adults within a phase III safety trial. Vaccine. 2008;26(19):2378-88.

8. Fazekas G, Martosne-Mendi R, Jankovics I, Szilvasy I, Vajo Z. Cross-reactive immunity to clade 2 strains of influenza virus A subtype H5N1 induced in adults and elderly patients by Fluval, a prototype pandemic influenza virus vaccine derived by reverse genetics, formulated with a phosphate adjuvant, and directed to clade 1 strains. Clin Vaccine Immunol. 2009;16(4):437-43.

9. Ehrlich HJ, Müller M, Fritsch S, Zeitlinger M, Berezuk G, Löw-Baselli A, et al. A cell culture (Vero)-derived H5N1 whole-virus vaccine induces cross-reactive memory responses. J Infect Dis. 2009;200(7):1113-8.

10. Ehrlich HJ, Müller M, Oh HM, Tambyah PA, Joukhadar C, Montomoli E, et al. A clinical trial of a whole-virus H5N1 vaccine derived from cell culture. N Engl J Med. 2008;358(24):2573-84.

11. European Food Safety Authority. Opinion of the Scientific Panel on contaminants in the food chain [CONTAM] related to mercury and methylmercury in food. 24 February 2004 [cited 15 September 2009]. Available from: http://www.efsa. europa.eu/EFSA/efsa_locale-1178620753812_1178620763245.htm

12. Thompson WW, Price C, Goodson B, Shay DK, Benson P, Hinrichsen VL, et al Early thimerosal exposure and neuropsychological outcomes at 7 to 10 years. N Engl J Med. 2007;357(13):1281-92.
13. Tozzi AE, Bisiacchi P, Tarantino V, De Mei B, D’Elia L, Chiarotti F, et al. Neuropsychological performance 10 years after immunization in infancy with thimerosal-containing vaccines. Pediatrics. 2009;123(2):475-82.

14. Aschner M, Ceccatelli S. Are neuropathological conditions relevant to ethylmercury exposure? Neurotox Res. 16 September 2009 [Epub ahead of print]. doi:10.1007/s12640-009-9113-2.

15. Burbacher TM, Shen DD, Liberato N, Grant KS, Cernichiari E, Clarkson T. Comparison of blood and brain mercury levels in infant monkeys exposed to methylmercury or vaccines containing thimerosal. Environ Health Perspect. 2005;113(8):1015-21.

16. Institute of Medicine of the National Academies. Immunization Safety Review: Vaccines and Autism. Washington, DC: The National Academies Press; 2004. Available from: http://books.nap.edu/openbook.php?record_id=10997

17. European Medicines Agency. Pandemrix. Summary of product characteristics. [cited 15 October 2009]. Available from: http://www.emea.europa.eu/ humandocs/PDFs/EPAR/pandemrix/Pandemrix-PU-17-en.pdf

18. European Medicines Agency. Celvapan. Summary of product characteristics. [cited 15 October 2009]. Available from: http://www.emea.europa.eu/ humandocs/PDFs/EPAR/celvapan/spc/emea-spc-h982pu17en.pdf

19. European Medicines Agency. Focetria. Summary of product characteristics. [cited 15 October 2009]. Available from: http://www.emea.europa.eu/ humandocs/PDFs/EPAR/focetria/spc/emea-spc-h385en.pdf

20. Greenberg ME, Lai MH, Hartel GF, Wichems CH, Gittleson C, Bennet J, et al. Response after one dose of a monovalent influenza A (H1N1) 2009 vaccine preliminary report. N Engl J Med. 10 September 2009 [Epub ahead of print]. doi:10.10656/NEJMoa0907413.

21. Clark TW, Pareek M, Hoschler K, Dillon H, Nicholson KG, Groth N, et al. Trial of influenza A (H1N1) 2009 monovalent MF59-adjuvanted vaccine - preliminary report. N Engl J Med. 10 September 2009 [Epub ahead of print]. doi:10.1056/ NEJMoa0907650.

22. Országos Gyógyszerészeti Intézet (National Institute of Pharmacy). Fluval $P$ szuszpenziós injekció. Betegtajékoztató. (Fluval P suspension for injection. Information for patients) [cited 15 October 2009]. Hungarian. Available from: http://www.ogyi.hu/fluval_p_ogyi_t_20970/

23. Valenciano $\mathrm{M}$, Ciancio $\mathrm{BC}$, Moren $\mathrm{A}$, the influenza vaccine effectiveness working group. First steps in the design of a system to monitor vaccine effectiveness during seasonal and pandemic influenza in EU/EEA Member States. Euro Surveill. 2008;13(43):pii=19015. Available from: http://www.eurosurveillance. org/ViewArticle.aspx?ArticleId $=19015$

24. European Centre for Disease Prevention and Control. Protocol for cohort database studies to measure influenza vaccine effectiveness in the European Union and European Economic Area Member States. Technical document. Stockholm: ECDC; 2009. Available from: http://ecdc.europa.eu/en/publications/ Publications/ 0907_TER_Influenza_AH1N1_Measuring_Influenza_Vaccine_ Effectiveness_Protocol_Cohort_Database_Studies.pdf

25. European Centre for Disease Prevention and Control. Protocol for case-control studies to measure influenza vaccine effectiveness in the European Union and European Economic Area Member States. Technical document. Stockholm: ECDC; 2009. Available from: http://ecdc.europa.eu/en/publications/Publications/ 0907_TED_Influenza_AH1N1_Measuring_Influenza_Vaccine_Effectiveness Protocol_Case_Control_Studies.pdf

26. European Medicines Agency. Pandemic influenza A(H1N1)v vaccines authorised via the core dossier procedure. Explanatory note on scientific considerations regarding the licensing of pandemic $A(H 1 N 1) v$ vaccines. 24 September 2009 [cited 15 October 2009]. Available from: http://www.emea.europa.eu/pdfs/ human/pandemicinfluenza/60825909en.pdf

27. Schonberger LB, Bregman DJ, Sullivan-Bolyai JZ, Keenlyside RA, Ziegler DW, Retailliau HF, et al. Guillain-Barre syndrome following vaccination in the National Influenza Immunization Program, United States, 1976-1977. Am J Epidemiol. 1979;110(2):105-23.

28. Tam CC, O’Brien SJ, Petersen I, Islam A, Hayward A, Rodrigues LC. GuillainBarré syndrome and preceding infection with campylobacter, influenza and Epstein-Barr virus in the general practice research database. PLoS One. 2007;2(4):e344.

29. Stowe J, Andrews N, Wise L, Miller E. Investigation of the temporal association of Guillain-Barre syndrome with influenza vaccine and influenza-like illness using the United Kingdom General Practice Research Database. Am J Epidemiol. 2009;169(3):382-8.

30. Eurosurveillance editorial team. ECDC in collaboration with the VAESCO consortium to develop a complementary tool for vaccine safety monitoring in Europe. Euro Surveill. 2009;14(39):pii=19345. Available from: http://www. eurosurveillance.org/ViewArticle.aspx?ArticleId=19345

31. World Health Organization. Meeting of Global Advisory Committee on Vaccine Safety, 18-19 June 2008. Wkly Epidemiol Rec. 2008;83(32):287-92.

32. Jordan R, Hayward A. Should healthcare workers have the swine flu vaccine? BMJ. 2009 Aug 25;339:b3398. doi: 10.1136/bmj.b3398. 
33. European Centre for Disease Prevention and Control. Pandemic H1N1 2009. ECDC interim risk assessment. 25 September 2009 [cited 15 October 2009]. Available from: http://ecdc.europa.eu/en/healthtopics/Documents/0908_ Influenza_AH1N1_Risk_Assessment.pdf

34. European Centre for Disease Prevention and Control. Revised pandemic 2009 planning assumptions for Europe. 18 September 2009 [cited 15 October 2009]. Available from: http://ecdc.europa.eu/en/activities/sciadvice/Lists/ECDC\%20 Reviews/ECDC_DispForm.aspx?List=512ff74f\%2D77 d4\%2D4ad8\%2Db6d6\%2Dbfof2 $3083 f 30 \& I D=650$

35. Australian Government Department of Health and Ageing. Australia's response and data. [cited 15 October 2009]. Available from: http://www. healthemergency.gov.au/internet/healthemergency/publishing.nsf/Content/ resources

36. Baker MG, Wilson N, Huang QS, Paine S, Lopez L, Bandaranayake D, et al. Pandemic influenza $A(H 1 N 1) v$ in New Zealand: the experience from April to August 2009. Euro Surveill. 2009;14(34):pii=19319. Available from: http://www. eurosurveillance.org/ViewArticle. aspx?ArticleId=19319

37. European Commission. Influenza A (H1N1): EU Health Security Committee agrees statement on target and priority groups for vaccination. Press release. 25 August 2009 [ cited 15 October 2009]. Available from: http://europa.eu/rapid/ pressReleasesAction.do? reference $=\mathrm{IP} / 09 / 1252$

38. Jain S, Kamimoto L, Bramley AM, Schmitz AM, Benoit SR, Louie J, et al. Hospitalized patients with 2009 A1N1 influenza in the United States, AprilJune 2009. N Engl J Med. 8 October 2009 [Epub ahead of print]. doi:10.1056/ NEJMoa0906695.

39. Jamieson DJ, Honein MA, Rasmussen SA, Williams JL, Swerdlow DL, Biggerstaff MS, et al. H1N1 2009 influenza virus infection during pregnancy in the USA. Lancet. 2009;374(9688):451-8.

40. Skowronski DM, De Serres G. Is routine influenza immunization warranted in early pregnancy? Vaccine. 2009;27(35):4754-70.

41. Centers for Disease Control and Prevention (CDC). Surveillance for pediatric deaths associated with 2009 pandemic influenza A (H1N1) virus infection - United States, April-August 2009. MMWR Morb Mortal Wkly Rep. 2009;58(34):941-7.

42. The ANZIC Influenza Investigators. Critical Care Services and 2009 H1N1 Influenza in Australia and New Zealand. N Engl J Med. 8 October 2009 [Epub ahead of print]. doi:10.1056/NEJMoa0908481.

43. European Centre for Disease Prevention and Control. Why healthcare workers are a priority group for pandemic influenza $A(\mathrm{H} 1 \mathrm{~N} 1)$ vaccination? 6 October 2009 [cited 15 October 2009]. Available from: http://ecdc.europa.eu/en/ activities/sciadvice/Lists/ECDC\%20Reviews/ECDC_DispForm.aspx?List=512ff74f $\% 2$ D77d4\%2D4ad8\%2Db6d6\%2Dbf0f23083f30\&ID $=664$

44. Griffin MR, Braun MM, Bart KJ. What should an ideal vaccine postlicensure safety system be? Am J Public Health. 2009 0ct;99 Suppl 2:S345-50.

45. van Doorn PA. What's new in Guillain-Barré syndrome in 2007-2008? J Peripher Nerv Syst. 2009;14(2):72-4.

46. European Centre for Disease Prevention and Control. ECDC Interim Guidance. Use of specific pandemic influenza vaccines during the H1N1 2009 pandemic. Stockholm: ECDC; August 2009 [cited 15 October 2009]. Available from: http:// www.ecdc.europa.eu/en/publications/Publications/ 0908_GUI_Pandemic_ Influenza_Vaccines_during_the_H1N1_2009_Pandemic.pdf

47. Mereckiene J, Cotter S, Nicoll A, Lévy-Bruhl D, Ferro A, Tridente G, et al. National Seasonal Influenza Vaccination Survey in Europe, 2008. Euro Surveill. 2008;13(43):pii=19017. Available from: http://www.eurosurveillance.org/ ViewArticle.aspx?ArticleId $=19017$

48. Swedish Presidency of the European Union. EU health ministers on the new influenza. Press release. 12 October 2009 [cited 15 October 2009]. Available from: http://www.se2009.eu/en/meetings_news/2009/10/12/eu_health ministers_on_the_new_influenza 